\title{
DEVELOPING A QUESTIONNAIRE ON MEASURING THE LEARNING MOTIVATION IN READING QURAN
}

\author{
Yusuf Hanafi \\ Universitas Negeri Malang \\ Jl. Semarang No. 5 Malang, Indonesia, 65145 \\ Email: yusuf.hanafi.fs@um.ac.id \\ Muhammad Saefi \\ Universitas Negeri Malang \\ Jl. Semarang No. 5 Malang, Indonesia, 65145 \\ Email: msaefi34@yahoo.com
}

\section{Alifudin Ikhsan}

Universitas Negeri Malang

Jl. Semarang No. 5 Malang, Indonesia, 65145

Email: um.alifudin93@gmail.com

\section{Tsania Nur Diyana}

Universitas Negeri Malang

Jl. Semarang No. 5 Malang, Indonesia, 65145

Email: tsanianurdiyana@gmail.com

\section{Abd Rauf Hassan}

Universiti Putra Malaysia

Serdang 43400 Selangor Malaysia

Email: raufhassan2011@gmail.com

\author{
Nurul Murtadho \\ Universitas Negeri Malang \\ Jl. Semarang No. 5 Malang, Indonesia, 65145 \\ Email: nurul.murtadho.fs@um.ac.id
}

Received: 04, 2021. Accepted: 06, 2021. Published: 06, 2021.

\begin{abstract}
Learning motivation has been examined for its positive influence on learning outcomes. However, little attention has been addressed to the development of measuring instruments of learning motivation in the context of reading the Quran in Indonesian higher education. This study was designed to develop a Quran learning motivation questionnaire. The Self-Determination Theory (SDT) was applied as a theoretical framework to explore the type dan level of motivation. Participants involved in this study were 420 students. They were divided into subsample one for exploratory factor analysis $(\mathrm{N}=200)$ and subsample two with confirmatory factor analysis $(\mathrm{N}=220)$. The questionnaire was developed with 12 item-three factors using five points Likert scale that can measure the learning motivation in reading Quran. The results of the study show that the level of student motivation is relatively low $(\mathrm{M}=3.12)$, and the intrinsic motivation type $(M=3.99)$ is more dominant than extrinsic motivation survival $(M=$ 2.99) and approval $(M=2.38)$ with a $\mathrm{p}$-value of 0.000 . In addition, it was found that female students $(M=3.19)$ had significantly higher motivation than male students $(M=3.04)$, with a $\mathrm{p}$-value of 0.017 .

Keywords: Confirmatory Factor Analysis, Exploratory Factor Analysis, Gender, Motivation Scale, Quran
\end{abstract}




\begin{abstract}
ABSTRAK
Motivasi belajar telah diuji pengarubnya yang positif terhadap hasil belajar. Namun, sedikit perhatian yang ditujukan pada pengembangan alat ukur motivasi belajar dalam konteks membaca Al-Qur'an di perguruan tinggi Indonesia. Penelitian ini dirancang untuk mengembangkan angket motivasi belajar Al-Qur'an. Self-Determination Theory (SDT) diterapkan sebagai kerangka teoritis untuk mengeksplorasi jenis dan tingkat motivasi. Partisipan yang terlibat dalam penelitian ini 420 peserta didik. Mereka dibagi menjadi subsampel satu untuk analisis faktor eksplorasi $(N=200)$ dan subsampel dua dengan analisis faktor konfirmatori $(N=220)$. Kuesioner dikembangkan dengan 12 item; tiga faktor menggunakan skala Likert lima poin yang dapat mengukur motivasi belajar dalam membaca Al-Qur'an. Hasil penelitian menunjukean bahwa tingkat motivasi belajar peserta didik relatif rendah $(M=3,12)$, dan jenis motivasi intrinsik $(M=3$,99) lebih dominan dibandingkan motivasi ekstrinsik kelangsungan hidup $(M=2,99)$ dan persetujuan $(M=2,38)$ dengan nilai $p$ 0,000. Selain itu, ditemukan babwa peserta didik perempuan $(M=3,19)$ memiliki motivasi jauh lebih tinggi daripada peserta didik laki-laki $(M=3,04)$, dengan p-value 0,017.
\end{abstract}

Kata Kunci: Analisis Faktor Konfirmatori, Analisis Faktor Eksplorasi, Gender, Skala Motivasi, Al-Qur'an

\title{
INTRODUCTION
}

The ability to read the Quran must be possessed by every Muslim since it is directly related to their religious activities. Reading Quran activity is of paramount importance in Islam. In recent years, there has been growing competition in reading the Quran from local to international levels. A significant award is given to students who demostrate best achievements in reading Quran. This condition illustrates that there are two main reasons for students learn to read Quran. First, the need for Quran reading ability (internal) and Second, the desire to achieve an award from Reading Quran ability (external). These two reasons reflect the growing trend of reading Quran among student. In this context, the reasons for reading Quran are in line with the theory hailed in psychology that is Self-determination Theory (SDT) (Ryan \& Deci, 2020, 2000).

SDT is a widely used motivation theory in various studies. According to this theory, learning motivation consists of extrinsic and intrinsic motivation. While intrinsic motivation refers to interests and curiosity, extrinsic motivation adresses the desire to receive a gift or praise (Pintrich, 2004). If the former refers to the human tendency to learn as a part of themselves, the latter is a combination of external control and self-regulation (Ryan \& Deci, 2020, 2000). SDT can help us distinguish motivation between controlled and self-determined (Deci et al.,, 1991). The theory asserts that these two types are distinct and operate on a single continuum (Chen \& Jang, 2010). Given this theory, intrinsic motivation is at the opposite end of the continuum and extrinsic motivation falls within the middle of the continuum (Ryan \& Deci, 2000). SDT, when used as a theoretical lens, can argue that student involvement in learning arises from their motivation (Fried \& Konza, 2013; Newbery, 2012). In other words, students' motivation leads to and facilitates their active involvement in the learning process (Lee \& Reeve, 2012). In summary, SDT helps this research to synthesize findings on how student motivation is related to their competence and autonomy specifically in the context of Quran learning (Leach, 2016).

In a particular learning process, students' motivation needs to be explored by their teachers. Their learning motivation is closely related to their learning outcomes (Albrecht \& Karabenick, 2018; Sogunro, 2014). Their lack of motivation can cause them to feel depressed and vice versa. Therefore, the teachers need to be aware and able to manage well their student motivation (Kunanitthaworn et al., 2018).

Students' motivation level and type are the most frequently studied and they can be used as a catalyst in establishing appropriate learning interventions (Basturkmen, 2010; Schumacher \& Ifenthaler, 2018). A good understanding on students' motivation may contribute and increase their potential retention while studying at university (Ballmann \& Mueller, 2008; Seli, 
Wammes, Risko, \& Smilek, 2016). It is extremely important to manage the efforts to understand students' learning motivation. Their learning motivation is more essential than their involvement in the learning process (Day, Kelley, Browne, \& Kohn, 2020; Hsieh, 2014). It goes without saying that students' learning motivation is a fundamental element that teachers should explore to improve their learning achievement and at the same time to tackle some problems that hinder students' learning process (Triyanto, 2019).

In education contenxt, students' learning motivation has been studied by researchers. Some studies discuss questionnaire development to measure students' learning motivation based on SDT. However, little attention has been addressed to questionnaires development in the context of learning to read the Quran especially concerning students in Indonesian higher education. Learning to read the Quran displays a different academic atmosphere.

Recent research reported that quality of learning Quran is decreasing (Berglund, 2017; Berglund \& Gent, 2019). It may have something to do with the students' motivation and academic circumstance. The academic atmosphere is a significant factor influencing student motivation (Wang \& Degol (2016). Research on students' learning motivation in higher education also received less attention (Day et al., 2020; Kember, Hong, \& Ho, 2008). Adult motivation for learning is still a rarely studied topic under the framework of contemporary motivational theories such as SDT (Rothes, Lemos, \& Gonçalves, 2017). This evidence-based theory can help develop learning programs with a positive academic atmosphere for students. The present research focuses on measuring the level and type of student learning motivation using instruments that result in adaptation and revalidation. The adaptation was chosen since it takes a long time to develop new ones.

Personal characteristics, such as gender, can also influence student motivation, especially in adulthood (Rothes et al., 2017). Gender is a relevant predictor in the study of academic motivation (Heyder, Weidinger, \& Steinmayr, 2021; Kunanitthaworn et al., 2018). The influence of gender on student motivation has been widely studied. It is argued that women are more motivated to learn than men (King \& Ganotice, 2014; Marinak \& Gambrell, 2010; Rothes et al., 2017). In this study, gender is counted as a variable differentiating level of motivation among male and female students. Taking into account gender predictors is important in investigating learning to read the Quran in universities and schools in Indonesia. Especially in Pondok pesantren (Islamic boarding schools) the circumstance of learning Quran was carried out with gender segregation (Srimulyani, 2007). The segregation is also very common, even in non-religious classes in Arab and Muslim-majority countries (AlMatrouk, 2016; Roula, 2004). On the other hand, the impact of gender segregation on learning motivation is still a matter of intense debate until now (Gleason, 2011). This condition reflects a global issue which needs scholarly attention from scholars.

To date, there has been no previous research discussing the comparison of learning motivation in terms of gender in the context of learning the Quran. More studies need to be done in the future to contribute well-informed results and conclusions on this issue. This study tries to fill the gap and to contribute to the body of knowledge. It aimed to develop a Quran learning motivation questionnaire.

\section{METHOD}

The data were collected in the even semester of the 2018-2019 academic year at the State University of Malang, Indonesia. The sample employed in this study were 420 first-year students aged 18-20 years who had taken a Quran learning for one semester. Quran learning is a compulsory program for all new students and is part of the Islamic religious education course. This program is held for two hours every weekend. Activities carried out in groups accompanied by a tutor. This sample was then divided into two subsamples. Subsample one, 
consisting of 200 students (36 male and 164 female), was used for Exploratory Factor Analysis (EFA), while subsample two, composed of 220 students (110 male and 110 female), was used for Confirmatory Factor Analysis (CFA). Students might choose not to respond to the questionnaire because it was voluntary. Researchers had also informed them that filling out the questionnaire did not contribute to their final grades.

The instrument used in this study adopted questionnaire developed by Choy, Goh, \& Sedhu (2016) and Nielsen (2018). The researchers named the questionnaire Motivation to Learn Reading Quran Questionnaire (MLRQ2). They went through several steps. First, they translated the questionnaire statement items into the participants' national language. Second, they selected the appropriate statement items for use in the context of learning to read the Quran. Adjustments were also made by replacing a number of words without changing the basic meaning. Third, they checked several instructors of the Quran learning and the selected items.

When it came to validation, three experts in the field of Islamic religious education took a part in this step. The item is maintained if all experts declare a "yes" choice for conformity. A series of the compilation of these items found that 14 statement items consisting of 6 items for internal motivation (In1-In6) and eight items for external motivation (Ex1-Ex8) were appropriate for this study. These 14 items were then given to five students as potential respondents for better improvement. We used a five-point Likert scale recommended by Gable \& Wolf (1993) in psychometric measurement, especially the school's practical dimension.

The learning motivation factor has been determined in the previous instrument. However, this research began with an exploratory factor analysis because the learning context is much different. Besides, the development of a questionnaire to measure intrinsic and extrinsic motivation was limited to prevalidation with the Rasch model (Nielsen, 2018). Thus, this study's revalidation uses two stages that contain strong properties by following the method discussed by Gerbing \& Anderson (1988). An evaluation of instrument factors' structure was carried out to answer the first question. The review was carried out in four stages: analysis with descriptive statistics and bivariate correlation for all total item scores, EFA, CFA, and internal consistency checks by calculating Cronbach's alpha $(\alpha)$, Construct Reliability (C.R.), Average Variance Extracted (AVE), and concurrent validity by calculating correlations between factors. A one-way Anova test was conducted to determine the effect of gender on the motivation to learn Quran reading.

\section{RESULTS AND DISCUSSION}

\section{Descriptive Analysis and Bivariate Correlation}

There are some differences between bivariate analysis and univariate analysis. While univariate analysis deals only with one variable, bivariate correlation describes the effect that two or more phenomena occur together and therefore they are linked. The average score of statement items is from 2.05 to 4.36 , with a standard deviation ranging from 0.78 to 1.21 . The correlation of total item scores using bivariate correlation to check empirical validity shows that the $\mathrm{r}$-value is in the range of 0.216 to 0.543 , with a $\mathrm{p}$-value $<0.01$. All items were retained because they met the conditions (did not reach 2.5 SD from the mean and had a strong correlation between items with a value of $\mathrm{r}<0.80$ ) under research conducted by Field (2013) and Meyers, Gamst, \& Guarino (2017).

\section{Exploratory Factor Analyses}

The statement items are maintained if the loading factor is more than 0.5 (Guadagnoli \& Velicer, 1988). The analysis results applied Principal Components Analysis (PCA) with varimax rotation in subsample one. It shows that 14 items are grouped into three cleanest 
factors. Factor 1 is the internal motivation $(\operatorname{In} 1-\operatorname{In} 6)$, factor 2 is external motivation approval (Ex1-Ex4), and factor 3 is external survival motivation (Ex5-Ex8). The Kaiser-Meyer-Olkin (KMO) value of 0.811 shows an excellent sample (Kaiser, 1970), far exceeding the set threshold of 0.6 (MacCallum, Widaman, Zhang, \& Hong, 1999). Bartlett 'test $\chi^{2} /(91)=$ 965.452, p-value 0,000 shows multivariate normally distributed data and can provide strong support for factor analysis (Kaiser, 1970). The Measures of Sampling Adequacy (MSA) value for all items is more than 0.5 . The total variance of $60.66 \%$ is within a reasonable range for social sciences research (Kline, 1994). Eigenvalue values for the three factors in order are 4.682, 2.378, and 1.434. Table 1 below provides more detailed results.

Table 1. Exploratory Factor Analysis of 14 Items

\begin{tabular}{|c|c|c|c|}
\hline \multirow[t]{2}{*}{ Factor } & \multicolumn{3}{|c|}{ Component } \\
\hline & 1 & 2 & 3 \\
\hline \multicolumn{4}{|c|}{ Factor 1} \\
\hline In1 & 0.866 & & \\
\hline In2 & 0.853 & & \\
\hline In3 & 0.844 & & \\
\hline In4 & 0.799 & & \\
\hline In5 & 0.729 & & \\
\hline In6 & 0.503 & & \\
\hline \multicolumn{4}{|c|}{ Factor 2} \\
\hline Ex1 & & 0.793 & \\
\hline Ex2 & & 0.759 & \\
\hline Ex3 & & 0.723 & \\
\hline Ex4 & & 0.712 & \\
\hline \multicolumn{4}{|c|}{ Factor 3} \\
\hline Ex5 & & & 0.819 \\
\hline Ex6 & & & 0.707 \\
\hline Ex7 & & & 0.661 \\
\hline Ex8 & & & 0.654 \\
\hline Eigenvalue & 4.682 & 2.378 & 1.434 \\
\hline$\%$ of variance & 33.439 & 16.983 & 10.242 \\
\hline Cumulative $\%$ & 33.439 & 50.423 & 60.665 \\
\hline
\end{tabular}

\section{Confirmatory Factor Analysis}

The results of the initial validation in subsample two with CFA using maximum likelihood estimation for correlated models in Figure 1 on 14 item-3 factors indicate a poor match with the value $(\chi 2 / \mathrm{df})=2,603$ with $\mathrm{p}$-value of 0,000 , SRMR $=0.114$, RMSEA $=0.086$, $\mathrm{CFI}=0.922$, GFI $=0.889$, and TLI $=0.904$. SRMR values $(>0.08)$, RMSEA $(>0.06)$, and GFI $(<0.9)$ in the initial model have not yet reached the threshold suggested by $\mathrm{Hu} \&$ Bentler (1999). An examination of the standardized regression weights $(\lambda)$ values shows that the Ex2 and Ex4 items are less than 0.5. Besides, an examination of modification indices allows covariance between e4 and e5 (error terms for In 4 and In5). The removal of Ex 2 and Ex4 items and the addition of covariance terms e 4 and e 5 significantly increased the model's fit indices with a value $(\chi 2 / \mathrm{df})=1.702$ with a $\mathrm{p}$-value of $0.001, \mathrm{SRMR}=0.066$, RMSEA $=0.051$, $\mathrm{CFI}=0.941, \mathrm{GFI}=0.940$, and TLI $=0.967$. The revised model in Figure 2 shows a good fit by the recommended limits (Hu \& Bentler, 1999; McCoach, Gable, \& Madura, 2013; Weston $\&$ Gore, 2006). All items have a value of $\lambda$, and a factor loading above 0.5 indicates that the observed variables are strong enough to reflect the construct variables (Tabachnick \& Fidell, 2007). 


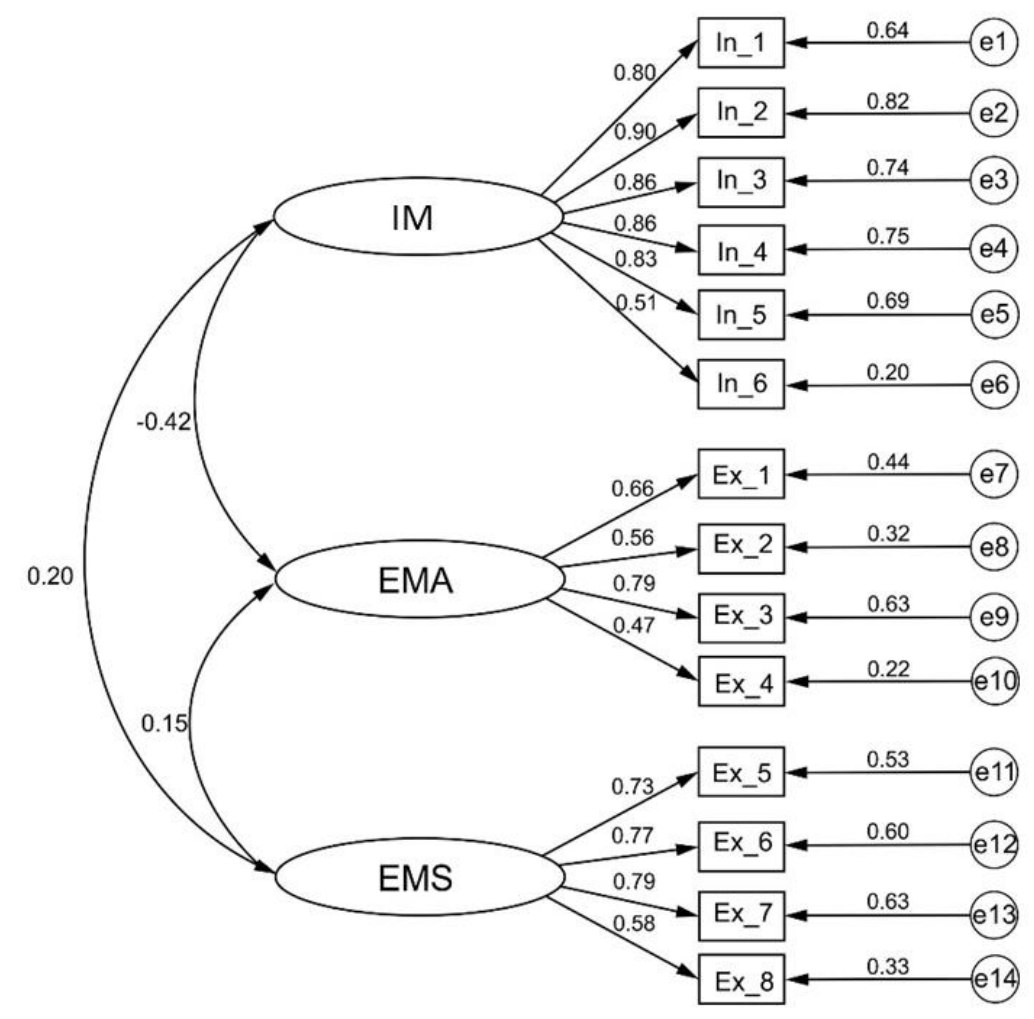

Figure 1. Three-Factors Correlated Model of the MLRQ2.

Note. IM = Internal Motivation, EMA = External Motivation Approval, EMS = External Motivation Survival

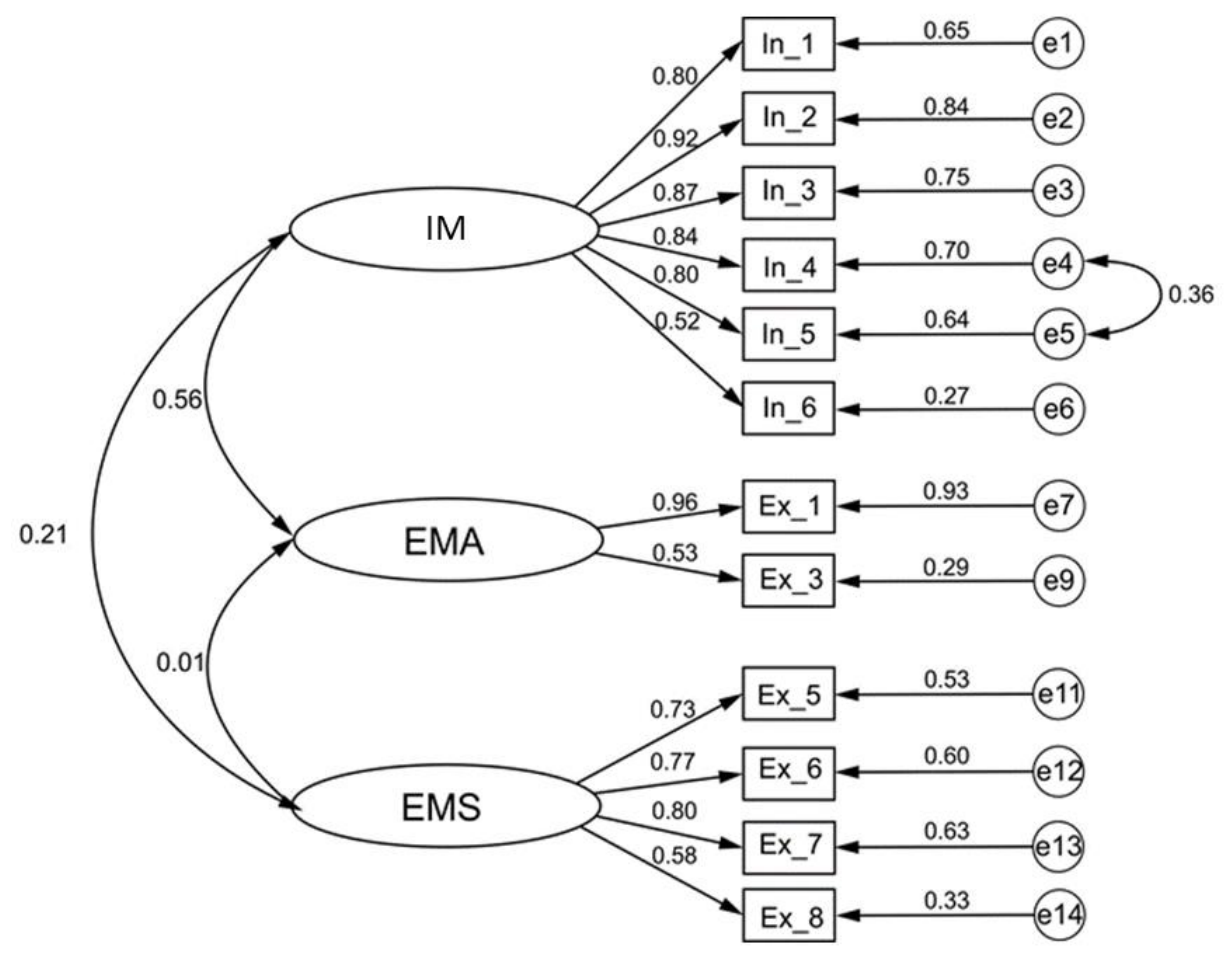

Figure 2. Three-Factors Correlated Model Revision of the MLRQ2. 


\section{Internal Consistency}

Internal consistent checks show AVE values of 0.52 to 0.64 . CR value of 0.74 to 0.91 . While the $\alpha$ value of 0.68 to 0.91 , with an $\alpha$ value for the whole item of 0.72 . Values of $\alpha$, C.R., and AVE meet the recommended threshold of >0.6, 0.7, and 0.5 (Hair, 2010). Refer to Table 2 for more detailed results. The concurrent validity results in Table 3 show that factor 1 is negatively correlated with factor 2 , whereas factor 3 is significantly positive. The correlation between factors 2 and 3 is positive but not significant. This result is consistent with the CFA results on the revised correlated model.

Table 2. C.R., AVE, and $\alpha$ of 12 Items-3 Factors

\begin{tabular}{|c|c|c|c|c|}
\hline \multirow[t]{2}{*}{ Factor } & \multicolumn{4}{|c|}{ Criteria } \\
\hline & $\Lambda$ & CR & AVE & $\alpha$ \\
\hline \multicolumn{5}{|c|}{ Factor 1 Intrinsic Motivation (I.M.) } \\
\hline In1. Learning to read Quran is essential for me & 0.805 & \multirow{6}{*}{0.91} & \multirow{6}{*}{0.64} & \multirow{6}{*}{0.91} \\
\hline $\begin{array}{l}\text { In2. The most exciting part of this Quran learning } \\
\text { is when I learn tajwid }\end{array}$ & 0.918 & & & \\
\hline $\begin{array}{l}\text { In3. I am challenged to understand tajwid very well } \\
\text { so I can later read Quran well }\end{array}$ & 0.866 & & & \\
\hline In4. I think learning to read Quran is joyful & 0.835 & & & \\
\hline $\begin{array}{l}\text { In5. I have been engaged in learning to read Quran } \\
\text { from secondary school to the university level }\end{array}$ & 0.800 & & & \\
\hline $\begin{array}{l}\text { In6. I choose to persistently enjoy this learning, } \\
\text { although I cannot read Quran very well. }\end{array}$ & 0.522 & & & \\
\hline \multicolumn{5}{|c|}{ Factor 2 Extrinsic Motivation-Approval (EMA) } \\
\hline $\begin{array}{l}\text { Ex1. I want to be a famous student in reading } \\
\text { Quran. }\end{array}$ & 0.964 & \multirow{2}{*}{0.74} & \multirow{2}{*}{0.61} & \multirow{2}{*}{0.68} \\
\hline $\begin{array}{l}\text { Ex2. The skills of reading the Quran are essential } \\
\text { for me to show to my family, friends, and lecturers. }\end{array}$ & 0.535 & & & \\
\hline \multicolumn{5}{|l|}{ Factor 3 Extrinsic Motivation-Survival (EMS) } \\
\hline $\begin{array}{l}\text { Ex5. I learn to read Quran so that I can pass the } \\
\text { exam }\end{array}$ & 0.730 & \multirow{4}{*}{0.81} & \multirow{4}{*}{0.52} & \multirow{4}{*}{0.80} \\
\hline Ex6. I learn to read Quran because of my parents. & 0.772 & & & \\
\hline $\begin{array}{l}\text { Ex7. I learn to read Quran because of my university } \\
\text { regulation. }\end{array}$ & 0.796 & & & \\
\hline Ex8. I learn to read Quran because of my friends & 0.576 & & & \\
\hline Total & & & & 0.72 \\
\hline
\end{tabular}

Table 3. Concurrent Validity

\begin{tabular}{cccc}
\hline & Factor 1 & Factor 2 & Factor 3 \\
\hline Factor 1 & 1 & & \\
\hline Factor 2 & $-0.449^{* *}$ & 1 & \\
\hline Factor 3 & $0.147^{*}$ & 0.054 & 1 \\
\hline Note. ${ }^{* *} p<0.01,{ }^{*} p<0.05$ & &
\end{tabular}

\section{The Effect of Gender}

The motivation profile of students in learning to read the Quran and the average total score of 3.12 is slightly higher than the middle point of the five scales. The investigation results showed that the highest average to the lowest sequential factors was internal motivation, external survival motivation, and external motivation approval. The paired t-test results are shown in Table 4 and Figure 3 to test the differences in these three factors. The 
internal motivation factor was significantly higher than the two external motivational factors, and the external survival factor was significantly higher than the external motivation factor of approval. One-way Anova test results, as shown in Table 5 and Figure 4 in the overall dimensions (total score), internal motivation factors, and external survival motivational factors of female students are significantly higher than male students. Meanwhile, in terms of external factors and external motivation for approval, male students are significantly higher than women.

Table 4. Paired Sample t-test by the Factor

\begin{tabular}{|c|c|c|c|c|c|}
\hline Pair & $\begin{array}{l}\text { Means } \\
\text { (S.D.) }\end{array}$ & $\begin{array}{c}\text { Mean } \\
\text { differences }\end{array}$ & $t$ & df & $\mathrm{p}$ \\
\hline Internal Motivation & $3.99(0.87)$ & & & & \\
\hline $\begin{array}{l}\text { External Motivation } \\
\text { Approval }\end{array}$ & $2.38(0.98)$ & 1.61 & 15.154 & 219 & $0.000^{* *}$ \\
\hline Internal Motivation & $3.99(0.87)$ & & & & \\
\hline External Motivation Survival & $2.99(0.88)$ & 1.00 & 13.042 & 219 & $0.000^{* *}$ \\
\hline $\begin{array}{l}\text { External Motivation } \\
\text { Approval }\end{array}$ & $2.38(0.98)$ & 0.61 & 7.050 & 219 & $0.000^{* *}$ \\
\hline External Motivation Survival & $2.99(0.88)$ & & & & \\
\hline
\end{tabular}

Table 5. Means (S.D.) MLRQ2 scores by the Gender

\begin{tabular}{lcccc}
\hline \multicolumn{1}{c}{ Factor } & Male & Female & $\mathbf{F}$ & $\mathbf{p}$ \\
\hline Total & $3.04(0.41)$ & $3.19(0.52)$ & 5.817 & $0.017^{*}$ \\
\hline Factor 1. Internal Motivation & $3.73(0.93)$ & $4.25(0.72)$ & 21.592 & $0.000^{* *}$ \\
\hline $\begin{array}{l}\text { Factor 2. External Motivation } \\
\text { Approval }\end{array}$ & $2.55(0.98)$ & $2.20(0.95)$ & 7.145 & $0.008^{* *}$ \\
\hline Factor 3. External Motivation Survival & $2.84(0.82)$ & $3.13(0.91)$ & 6.070 & $0.015^{*}$ \\
\hline Note. ${ }^{* *} p<0.01,{ }^{*} p<0.05$ & & & &
\end{tabular}

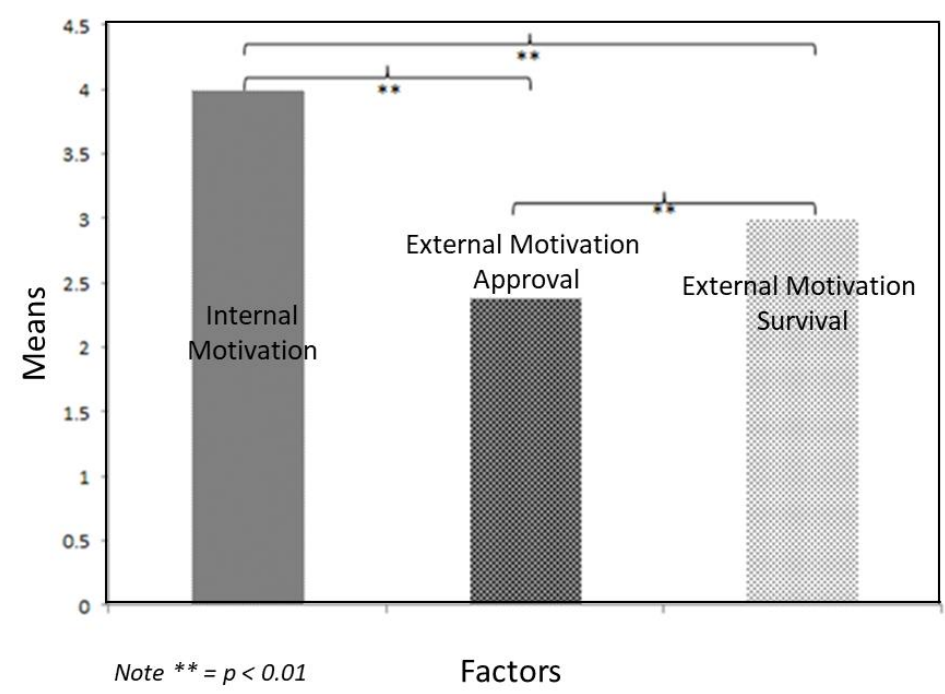

Figure 3. Paired Sample t-test by the Factor. 


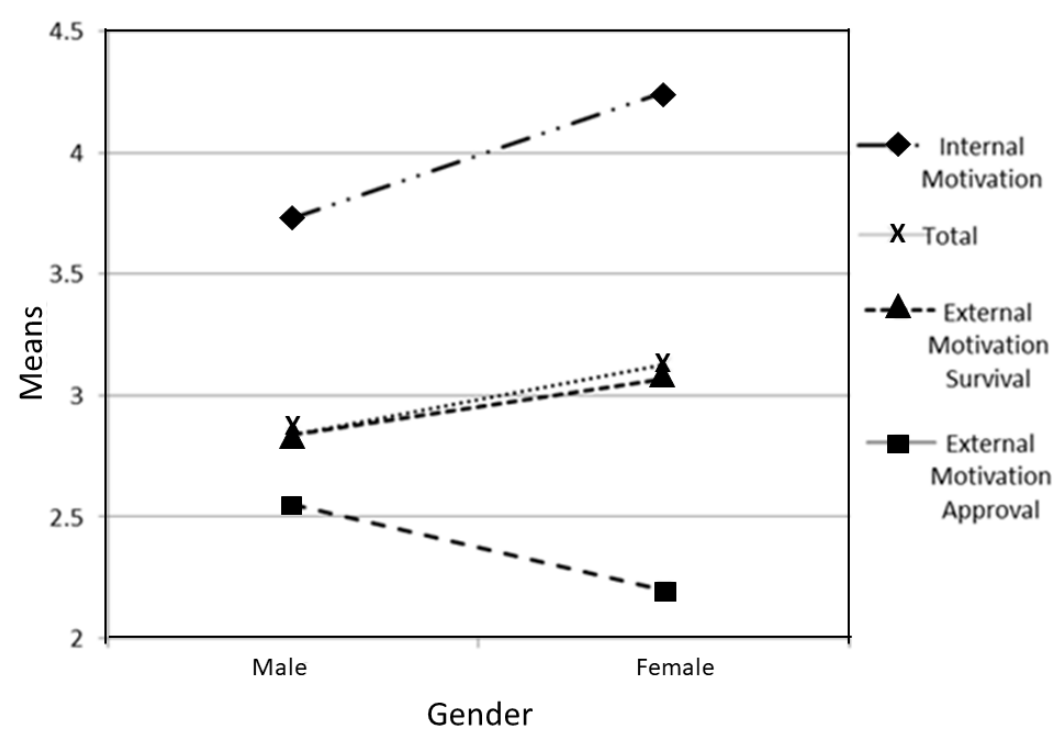

Figure 4. Means (S.D.) MLRQ2 Scores by the Gender.

This research attempts to validate the learning motivation questionnaire developed by Choy et al. (2016) and Nielsen (2018) in another context; that is, learning to read the Quran in higher education. The results of the study are relevant to the results of previous research (Sean \& Ahmed, 2012), contending that students are primarily motivated by extrinsic motivation (externally regulated) as well as intrinsic motivation (to know). Intrinsic motivation is strongly correlated with extrinsic motivation (Kunanitthaworn et al., 2018). These 12 item-3 factors of MLRQ2 in Table 2 use five Likert scales, from point 1 to disagree to 5 to strongly agree. The total score of this instrument ranges from 12 to 60, which is then divided by the number of items. The result is a score of $1-5$, with a higher score indicating a higher level of learning motivation.

Intrinsic motivation items explain that students enjoy learning to read the Quran and consider this ability to be valuable. To love learning is a personality trait and positive attribute that correlate significantly with intrinsic motivation (Kunanitthaworn et al., 2018). Intrinsic motivation in learning in higher education is associated with factors of relevance (Sogunro, 2014). Someone who has strong intrinsic motivation will be motivated to engage in reading activities for their interests, curiosity, or interest (Murphy \& Alexander, 2000).

Extrinsic motivation in this study is divided into approval and survival aspects. The approval factor is more likely to be recognizing others, while the survival factor is more likely to be their fear of authority (e.g., parents and lecturers). Factors influencing students' extrinsic motivation are family expectations and coercion, and peer acceptance. Rothes et al. (2017) explained that there are internal pressure sources; for example, it is illustrated in item 4, which states that students choose the Quran reading class because their friends followed the program. There is a sense of avoiding feelings of shame and inferiority to their peers.

This research shows that the level of student motivation in reading the Quran is inadequate. It has been explained that internal motivation has a strong relationship with selfregulated learning (SRL) (Ahmed, 2017). However, first-year students tend to have low SRL (Thibodeaux, Deutsch, Kitsantas, \& Winsler, 2017). Räisänen, Postareff, Mattsson, \& Lindblom-Ylänne (2018) explain that first-year students tend to be easily depressed because they do not have a good SRL.

Intrinsic motivation is classified as high and significantly different from extrinsic motivation. This study has shown that students have an awareness of learning to achieve the ability to read the Quran. These results are consistent with previous research that the first 
student's learning desire is intrinsic motivation. The second is recognition for being accepted in their community (approval) (Rothes et al., 2017; Sall1, 2017). It is essential to know the intrinsic motivation level (interest) because this element is rarely highlighted, even though it is beneficial as a coherent tool for analyzing and developing teaching and learning (Liu \& Hou, 2017). Intrinsic motivation is a significant predictor of personal and social improvement, and students can take more advantage, especially in self-understanding (Hsieh, 2014).

To improve the effectiveness of Quran learning, several supportive strategies can be applied. Linking curriculum content and learning activities with student interests and providing them opportunities to make choices can be explored (Orsini, Evans, Binnie, Ledezma, \& Fuentes, 2016). Active learning is very appropriate for students with high enough internal motivation and has the potential to promote their motivation (Andres, 2017) and Bolkan (2015). In higher education, it should be delivered with a variety of approaches (Tremblay-Wragg, Raby, Ménard, \& Plante, 2019)

The study found that external motivation was relatively low. Therefore, instructors may take extrinsic motivation into consideration to increase their intrinsic motivation (Saeed \& Zyngier, 2012). However, it should be noted that extrinsic rewards can also damage a person's sincerity or interest in learning (intrinsic motivation) (Bye, Pushkar, \& Conway, 2007).

The results of this study suggest that higher intrinsic motivation is strongly correlated with extrinsic motivation. This learning applies in language learning particularly for good reading skills (McGeown, Norgate, \& Warhurst (2012). Meanwhile, people with poor reading skills tend to show a strong correlation between intrinsic and extrinsic motivation. Based on these explanations, it is likely that most of the students in this study have poor Quran reading skills. This assumption is supported by the results of previous studies on participants with the same characteristics showing that the ability of students to read the Quran is indeed unsatisfactory (Hanafi et al., 2019).

In terms of gender difference, this study also uncovered that female student had significantly higher motivation than male students. The results of study are relevant to several previous studies, stating that women are more motivated than men in the learning process (King \& Ganotice, 2014; Marinak \& Gambrell, 2010), especially in intrinsic motivation (Rothes et al., 2017). Women have a higher motivation than men because they have a close relationship with family (Narknisorn \& Kusakabe, 2013). Other research results also show that intrinsic motivation and extrinsic motivation are strictly related to family support (Hong, Jeong, \& Downward, 2019; Kunanitthaworn et al., 2018).

The practical implication of the present study is that the teacher needs to provide a conducive and supportive classroom environment with various methods and strategies. If the teachers are able to meet those needs, their students are likely to learn the material effectively. There is strong evidence that the classroom environment plays a relatively more important role in determining their learning motivation for those with low abilities, especially if they are more vulnerable to self-criticism (Schick \& Phillipson, 2009). Apart from that, students with dominant intrinsic motivation can have more rapid learning development (Williams \& Williams, 2011). There is an intense desire within themselves to achieve learning goals (Ryan \& Deci, 2000).

When it comes to male student motivation, teachers and educational institutions need to consider some interventions by involving families to provide solid social supports for male students. Faculty should pay attention to the cooperation between the university/department and family in programs and activities that can improve student learning motivation (Ainissyifa \& Amelia, 2018). It is clear from the research evidence that social support interventions can increase male students' motivation, as explained in Personal Investment facilitating condition component (P.I.) Theory (King \& Ganotice, 2014). Another alternative in providing social 
support can be done by forming reading groups in a small size during the class learning process. This method enables students to increase their motivation in reading and this serves as social support for the students (Miller, 2015)

This study provides statistically reliable results. The sample used in this study was limited to one university's scope. Thus, generalization of findings can only be made to students with almost the same characteristics, for example, for students in Indonesia. More broadly, this research can be generalized from Indonesia to other countries in Southeast Asia and other countries with Muslim majority. In other words, this research cannot be generalized to for the context of students learning in universities and countries where Muslim is minority. Another limitation of the research relies solely on research conducted under the theoretical framework of SDT. This is to say that this present study did not cover the entire elements of SDT framework.

\section{CONCLUSION}

In addition to the development of a valid and reliable scale to explore learning motivation under SDT (KMO value of 0.811, Bartlett 'test $\chi 2 /(91)=965.452$, p-value 0,000 for EFA and $\left.\chi^{2} / \mathrm{df}\right)=1.702$ with a -value of 0.001, SRMR $=0.066$, RMSEA $=0.051, \mathrm{CFI}=0.941, \mathrm{GFI}=$ 0.940 , and TLI $=0.967$ for CFA), 12 item-3 factors, this study identified that the intrinsic motivation type is dominant 3.99) than extrinsic motivation survival (2.99) and approval (2.38) with $\mathrm{p}$-value of 0.000 , and gender as a predictor of academic motivation in Quran learning ( $\mathrm{p}=$ 0.017). It should be taken into consideration that this study has limited studies and scale developed and tested on this learning Quran issue in one university. This result can potentially assist faculty to identify and design programs and activities for the same characteristic students like Indonesia. Further study for the revalidation with larger samples to provide more valid and reliable results is suggested. It is recommended to apply to populations with different characteristics and to add more factors in the study of learning motivation in Quran reading. Lastly, research conducted to cover the entire model of SDT and the use of other motivation theories is encouraged.

\section{ACKNOWLEDGMENT}

We are grateful to the Research Institute and Community Engagement of Universitas Negeri Malang for their fundings in this study.

\section{BIBLIOGRAPHY}

Adcroft, A. (2011). The Motivations to Study and Expectations of Studying of Undergraduate Students in Business and Management. Journal of Further and Higher Education, 35(4), 521 543. https://doi.org/10.1080/0309877X.2011.590581

Ahmed, W. (2017). Motivation and Self-Regulated Learning: A Multivariate Multilevel Analysis. International Journal of Psychology and Educational Studies, 4(3), 1-11. https://doi.org/10.17220/ijpes.2017.03.001

Ainissyifa, H., \& Amelia, R. (2018). The Effect of Family Literacy Culture on Student's Motivation in Islamic Education Subject at State Senior High School in Garut. Jurnal Pendidikan Islam, 4(2), 11-24. https:/ / doi.org/10.15575/jpi.v4i2.2020

Albrecht, J. R., \& Karabenick, S. A. (2018). Relevance for Learning and Motivation in Education. The Journal of Experimental Education, 86(1), 1-10. https://doi.org/10.1080/00220973.2017.1380593

AlMatrouk, L. (2016). The Relationship between Gender Segregation in Schools, Self-Esteem, Spiritual Values/Religion, and Peer Relations in Kuwait. Near and Middle Eastern Journal of Research in Education, 2016(1), 1-26. https://doi.org/10.5339/nmejre.2016.3 
Andres, H. P. (2017). Active Teaching to Manage Course Difficulty and Learning Motivation. Journal of Further and Higher Education, 1-16. https://doi.org/ 10.1080/0309877X.2017.1357073

Ballmann, J. M., \& Mueller, J. J. (2008). Using Self-Determination Theory to Describe the Academic Motivation of Allied Health Professional-Level College Students. Journal of Allied Health, 37(2), 90-96. Retrieved from https://pubmed.ncbi.nlm.nih.gov/ 18630784/

Basturkmen, H. (2010). Developing Courses in English for Specific Purposes. London: Palgrave Macmillan UK. https://doi.org/10.1057/9780230290518

Berglund, J. (2017). Secular Normativity and the Religification of Muslims in Swedish Public Schooling. Oxford Review of Education, 43(5), 524-535. https://doi.org/10.1080/ 03054985.2017.1352349

Berglund, J., \& Gent, B. (2019). Quranic Education and Non-confessional RE: An Intercultural Perspective. Intercultural Education, 30(3), 323-334. https://doi.org/10.1080/ 14675986.2018.1539305

Blanchard, J. (2008). Learning Awareness: Constructing Formative Assessment in the Classroom, in the School and Across Schools. Curriculum Journal, 19(3), 137-150. https://doi.org/10.1080/09585170802357454

Bolkan, S. (2015). Intellectually Stimulating Students' Intrinsic Motivation: The Mediating Influence of Affective Learning and Student Engagement. Communication Reports, 28(2), 80-91. https://doi.org/10.1080/08934215.2014.962752

Brophy, J. (2004). Motivating Students to Learn, Second Edition (Second). Mahwah, N.J: Lawrence Erlbaum Associates.

Bye, D., Pushkar, D., \& Conway, M. (2007). Motivation, Interest, and Positive Affect in Traditional and Nontraditional Undergraduate Students. Adult Education Quarterly, 57(2), 141-158. https://doi.org/10.1177/0741713606294235

Chen, K. C., \& Jang, S. J. (2010). Motivation in Online Learning: Testing a Model of SelfDetermination Theory. Computers in Human Behavior, 26(4), 741-752. https://doi.org/10.1016/j.chb.2010.01.011

Choy, S. C., Goh, P. S. C., \& Sedhu, D. S. (2016). How and Why Students Learn: Development and Validation of the Learner Awareness Levels Questionnaire for Higher Education Students. International Journal of Teaching and Learning in Higher Education, 28(1), 94-101. Retrieved from https://eric.ed.gov/?id=EJ1106321

Day, M. C., Kelley, H. M., Browne, B. L., \& Kohn, S. J. (2020). Assessing Motivation and Learning Strategy Usage by Dually Enrolled Students. Smart Learning Environments, 7(1), 1-19. https://doi.org/10.1186/s40561-020-00131-w

Deci, E. L., Vallerand, R. J., Pelletier, L. G., \& Ryan, R. M. (1991). Motivation and Education: The Self-Determination Perspective. Educational Psychologist, 26(3-4), 325-346. https://doi.org/10.1080/00461520.1991.9653137

Field, A. (2013). Discovering Statistics Using IBM SPSS Statistics, 4th Edition (4th edition). SAGE Publications Ltd.

Fried, L., \& Konza, D. (2013). Using Self-Determination Theory to Investigate Student Engagement in the Classroom. International Journal of Pedagogy and Curriculum, 19, 27-40. https://doi.org/10.18848/2327-7963/CGP/v19i02/48898

Gable, R. K., \& Wolf, M. B. (1993). Instrument Development in the Affective Domain: Measuring Attitudes and V alues in Corporate and School Settings / (2nd ed.). Boston: Kluwer Academic Publishers, 
Gerbing, D. W., \& Anderson, J. C. (1988). An Updated Paradigm for Scale Development Incorporating Unidimensionality and Its Assessment. Journal of Marketing Research, 25(2), 186-192. https://doi.org/10.1177/002224378802500207

Gleason, P. (2011). Gender Segregated Learning Environments: An Analysis of the Perceived Impact of Single-sex Classrooms in South Carolina (Doctoral Dissertation, University of Central Florida). University of Central Florida, Florida, USA. Retrieved from https://stars.library.ucf.edu/etd/2039

Guadagnoli, E., \& Velicer, W. F. (1988). Relation of Sample Size to the Stability of Component Patterns. Psychological Bulletin, 103(2), 265-275. https://doi.org/10.1037/0033-2909.103.2.265

Hair, J. F. (Ed.). (2010). Multivariate Data Analysis (7. ed). Upper Saddle River, NJ: Pearson Prentice Hall.

Hanafi, Y., Murtadho, N., Hassan, A. R., Ikhsan, M. A., \& Diyana, T. N. (2019). Development and Validation of a Questionnaire for Teacher Effective Communication in Quran Learning. British Journal of Religious Education, 1-11. https://doi.org/10.1080/ 01416200.2019 .1705761

Heyder, A., Weidinger, A. F., \& Steinmayr, R. (2021). Only a Burden for Females in Math? Gender and Domain Differences in the Relation Between Adolescents' Fixed Mindsets and Motivation. Journal of Youth and Adolescence, 50(1), 177-188. https://doi.org/10.1007/s10964-020-01345-4

Hong, E., Jeong, Y., \& Downward, P. (2019). Perceived Organizational Support, Internal Motivation, and Work-Family Conflict among Soccer Referees. Managing Sport and Leisure, 24(1-3), 141-154. https://doi.org/10.1080/23750472.2019.1593049

Hsieh, T.-L. (2014). Motivation Matters? The Relationship among Different Types of Learning Motivation, Engagement Behaviors and Learning Outcomes of Undergraduate Students in Taiwan. Higher Education, 68(3), 417-433. https://doi.org/10.1007/s10734014-9720-6

Hu, L., \& Bentler, P. M. (1999). Cutoff Criteria for Fit Indexes in Covariance Structure Analysis: Conventional Criteria versus New Alternatives. Structural Equation Modeling: $A$ Multidisciplinary Journal, 6(1), 1-55. https://doi.org/10.1080/10705519909540118

Kaiser, H. F. (1970). A Second Generation Little Jiffy. Psychometrika, 35(4), 401-415. https://doi.org/10.1007/BF02291817

Kember, David., Hong, Celina., \& Ho, Amber. (2008). Characterizing the Motivational Orientation of Students in Higher Education: A Naturalistic Study in Three Hong Kong Universities. British Journal of Educational Psychology, 78(2), 313-329. https://doi.org/10.1348/000709907X220581

King, R. B., \& Ganotice, F. A. (2014). What's Happening to Our Boys? A Personal Investment Analysis of Gender Differences in Student Motivation. The Asia-Pacific Education Researcher, 23(1), 151-157. https://doi.org/10.1007/s40299-013-0127-4

Kline, P. (1994). An Easy Guide to Factor Analysis. London: Routledge.

Kunanitthaworn, N., Wongpakaran, T., Wongpakaran, N., Paiboonsithiwong, S., Songtrijuck, N., Kuntawong, P., \& Wedding, D. (2018). Factors Associated with Motivation in Medical Education: A Path Analysis. BMC Medical Education, 18(140), 1-9. https://doi.org/10.1186/s12909-018-1256-5

Leach, L. (2016). Enhancing Student Engagement in One Institution. Journal of Further and Higher Education, 40(1), 23-47. https://doi.org/10.1080/0309877X.2013.869565

Lee, W., \& Reeve, J. (2012). Teachers' Estimates of Their Students' Motivation and Engagement: Being in Synch with Students. Educational Psychology, 32(6), 727-747. https://doi.org/10.1080/01443410.2012.732385 
Liu, Y., \& Hou, S. (2017). Potential Reciprocal Relationship between Motivation and Achievement: A Longitudinal Study. School Psychology International, 1-18. https://doi.org/10.1177/0143034317710574

MacCallum, R. C., Widaman, K. F., Zhang, S., \& Hong, S. (1999). Sample Size in Factor Analysis. Psychological Methods, 4(1), 84-99. https://doi.org/10.1037/1082-989X.4.1.84

Marinak, B. A., \& Gambrell, L. B. (2010). Reading Motivation: Exploring the Elementary Gender Gap. Literacy Research and Instruction, 49(2), 129-141. https://doi.org/10.1080/19388070902803795

McCoach, D. B., Gable, R. K., \& Madura, J. P. (2013). Instrument Development in the Affective Domain. New York, NY: Springer New York. https://doi.org/10.1007/978-1-46147135-6

McGeown, S. P., Norgate, R., \& Warhurst, A. (2012). Exploring Intrinsic and Extrinsic Reading Motivation among Very Good and Very Poor Readers. Educational Research, 54(3), 309-322. https://doi.org/10.1080/00131881.2012.710089

Meyers, L. S., Gamst, G., \& Guarino, A. J. (2017). Applied Multivariate Research Design and Interpretation 3rd Edition. Thousand Oaks, CA: SAGE Publications, Inc. Retrieved from https://us.sagepub.com/en-us/nam/applied-multivariate-research/book246895

Miller, R. (2015). Learning to Love Reading: A Self-Study on Fostering Students' Reading Motivation in Small Groups. Studying Teacher Education, 11(2), 103-123. https://doi.org/10.1080/17425964.2015.1045771

Murphy, P. K., \& Alexander, P. A. (2000). A Motivated Exploration of Motivation Terminology. Contemporary Educational Psychology, 25(1), 3-53. https://doi.org/10.1006/ceps.1999.1019

Narknisorn, B., \& Kusakabe, K. (2013). Issues Challenging Future Thai Elder Care by Women and Family. International Journal of Sociology and Social Policy, 33(1/2), 21-32. https://doi.org/10.1108/01443331311295154

Newbery, G. (2012). The Psychology of Being Engaged and Its Implications for Promoting Engagement. In Engaging with Learning in Higher Education (pp. 47-69). Retrieved from https://researchdirect.westernsydney.edu.au/islandora/object/uws\%3A14353/

Nielsen, T. (2018). The Intrinsic and Extrinsic Motivation Subscales of the Motivated Strategies for Learning Questionnaire: A Rasch-Based Construct Validity Study. Cogent Education, 5(1), 1-19. https://doi.org/10.1080/2331186X.2018.1504485

Orsini, C., Evans, P., Binnie, V., Ledezma, P., \& Fuentes, F. (2016). Encouraging Intrinsic Motivation in the Clinical Setting: Teachers' Perspectives from the Self-Determination Theory. European Journal of Dental Education, 20(2), 102-111. https://doi.org/10.1111/eje.12147

Pintrich, P. R. (2004). A Conceptual Framework for Assessing Motivation and Self-Regulated Learning in College Students. Educational Psychology Review, 16(4), 385-407. https://doi.org/10.1007/s10648-004-0006-x

Räisänen, M., Postareff, L., Mattsson, M., \& Lindblom-Ylänne, S. (2018). Study-Related Exhaustion: First-Year Students' Use of Self-Regulation of Learning and Peer Learning and Perceived Value of Peer Support. Active Learning in Higher Education, 1-16. https://doi.org/10.1177/1469787418798517

Rothes, A., Lemos, M. S., \& Gonçalves, T. (2017). Motivational Profiles of Adult Learners. Adult Education Quarterly, 67(1), 3-29. https://doi.org/10.1177/0741713616669588

Roula, B. (2004). Gender-Segregated Education in Saudi Arabia: Its Impact on Social Norms and the Saudi Labor Market. Education Policy Analysis Archives, 12(28), 1-12. https://doi.org/10.14507/epaa.v12n28.2004 
Ryan, R. M., \& Deci, E. (2020). Intrinsic and Extrinsic Motivation from a Self-Determination Theory Perspective: Definitions, Theory, Practices, and Future Directions. Contemporary Educational Psychology, 61, 101860. https://doi.org/10.1016/j.cedpsych.2020.101860

Ryan, R. M., \& Deci, E. L. (2000). Intrinsic and Extrinsic Motivations: Classic Definitions and New Directions. Contemporary Educational Psychology, 25(1), 54-67. https://doi.org/10.1006/ceps.1999.1020

Saeed, S., \& Zyngier, D. (2012). How Motivation Influences Student Engagement: A Qualitative Case Study. Journal of Education and Learning, 1(2), 252-267. https://doi.org/10.5539/ jel.v1n2p252

Sall, A. (2017). Role of Motivation and Attitude: Learning Turkish and Greek in Cyprus. International Journal of Bilingualism, 136700691770345. https://doi.org/10.1177/ 1367006917703456

Schick, H., \& Phillipson, S. N. (2009). Learning Motivation and Performance Excellence in Adolescents with High Intellectual Potential: What Really Matters? High Ability Studies, 20(1), 15-37. https://doi.org/10.1080/13598130902879366

Schumacher, C., \& Ifenthaler, D. (2018). The Importance of Students' Motivational Dispositions for Designing Learning Analytics. Journal of Computing in Higher Education, 30(3), 599-619. https://doi.org/10.1007/s12528-018-9188-y

Sean, C. Y., \& Ahmed, P. K. (2012). Understanding Student Motivation in Higher Education Participation: A Psychometric Validation of the Academic Motivation Scale in the Malaysian Context. International Proceedings of Economics Development and Research, 53, 118122. Jurong West Singapore: International Association of Computer Science and Information Technology (IACSIT Press). https://doi.org/DOI: 10.7763/IPEDR. 2012. V53. 26

Seli, P., Wammes, J. D., Risko, E. F., \& Smilek, D. (2016). On the Relation between Motivation and Retention in Educational Contexts: The Role of Intentional and Unintentional Mind Wandering. Psychonomic Bulletin \& Review, 23(4), 1280-1287. https://doi.org/10.3758/s13423-015-0979-0

Sogunro, O. A. (2014). Motivating Factors for Adult Learners in Higher Education. International Journal of Higher Education, 4(1), 22-37. https://doi.org/10.5430/ijhe.v4n1p22

Srimulyani, E. (2007). Muslim Women and Education in Indonesia: The Pondok Pesantren Experience. Asia Pacific Journal of Education, 27(1), 85-99. https://doi.org/10.1080/02188790601145564

Tabachnick, B. G., \& Fidell, L. S. (2007). Using Multivariate Statistics (5th ed). Boston: Pearson/Allyn \& Bacon.

Thibodeaux, J., Deutsch, A., Kitsantas, A., \& Winsler, A. (2017). First-Year College Students' Time Use: Relations with Self-Regulation and GPA. Journal of Advanced Academics, 28(1), 5-27. https://doi.org/10.1177/1932202X16676860

Tremblay-Wragg, É., Raby, C., Ménard, L., \& Plante, I. (2019). The Use of Diversified Teaching Strategies by Four University Teachers: What Contribution to Their Students' Learning Motivation? Teaching in Higher Education, 1-18. https://doi.org/10.1080/ 13562517.2019 .1636221

Triyanto. (2019). The Academic Motivation of Papuan Students in Sebelas Maret University, Indonesia. SAGE Open, 9(1), 1-7. https://doi.org/10.1177/2158244018823449

Wang, M.-T., \& Degol, J. L. (2016). School Climate: A Review of the Construct, Measurement, and Impact on Student Outcomes. Educational Psychology Review, 28(2), 315-352. https://doi.org/10.1007/s10648-015-9319-1 
Weston, R., \& Gore, P. A. (2006). A Brief Guide to Structural Equation Modeling. The Counseling Psychologist, 34(5), 719-751. https://doi.org/10.1177/0011000006286345

Williams, K. C., \& Williams, C. C. (2011). Five Key Ingredients for Improving Student Motivation. Research in Higher Education Journal, 121-123. Retrieved from http://aabri.com/manuscripts/11834.pdf 